\title{
DETEKSI KUALITAS DAN KESEGARAN TELUR AYAM RAS BERDASARKAN DETEKSI OBJEK TRANSPARAN DENGAN METODE GREY LEVEL CO-OCCURRENCE MATRIX (GLCM) DAN KLASIFIKASI K-NEAREST NEIGHBOR (KNN)
}

\author{
Rizka Kaamtsaalil Salsabiilaa' ${ }^{1}$, Bambang Hidayat ${ }^{2}$, Sjafril Darana ${ }^{3}$ \\ 1,2 Prodi S1 Teknik Telekomunikasi, Fakultas Teknik Elektro, Universitas Telkom \\ ${ }^{3}$ Fakultas Peternakan, Universitas Padjadjaran \\ ${ }^{1}$ salsabiilaarizka@gmail.com, ${ }^{2}$ bhidayat@telkomuniversity.ac.id
}

\begin{abstract}
ABSTRAK
Telur adalah salah satu bahan pangan yang mudah dan lazim dijumpai di masyarakat Indonesia. Selain harganya murah, telur merupakan sumber nutrisi penting bagi kesehatan tubuh. Namun telur memiliki kualitas dan kesegaran yang berbeda-beda tergantung pada lingkungan penyimpanan dan kondisi induknya. Kesegaran telur dapat diketahui dari ketebalan dan kekentalan putih telurnya. Semakin tinggi putih telur semakin segar telur tersebut. Tebal atau tinggi albumen dapat diketahui dari nilai HU (Haugh Unit). Dalam makalah ini penulis membahas mengenai cara mendeteksi kualitas dan kesegaran telur menggunakan deteksi objek transparan dengan menggunakan metode GLCM (Grey Level Co-occurrence Method) dan klasifikasi KNN (K-Nearest Neighbor). Telur yang digunakan ialah telur ayam negeri. Pada penelitian ini dilakukan pengujian 51 citra telur, dengan komposisi masing-masing kelas memiliki 17 citra telur AA, 17 citra telur A, dan 17 citra telur B. Sehingga didapatkan akurasi terbaik sebesar 82.35\% dengan menggunakan metode GLCM (Grey Level Co-occurrence Matrix) dengan parameter orde dua kontras, energy, korelasi, homogenitas dan arah sudut 45 pada jarak $d=1$ dan kuantisasi yang digunakan adalah 8, dengan klasifikasi KNN (K-Neirest Neighbor) menggunakan jarak cosine pada K= 1 .
\end{abstract}

Kata kunci: Telur, HU (Haugh Unit), GLCM (Grey Level Co-occurrence Matrix), KNN (K-Neirest Neighbor)

\section{ABSTRACT}

Eggs are one of the common foods found in Indonesian society. In addition to its low prices, egg is one of important source of nutrients for the body health. However, egg have different qualities and freshness depending on the storage environment and the parent condition. The freshness of the egg can be known from the thickness of its albumen. More thicker the albumen, more fresh the egg is. The thickness can be known from the value of $\mathrm{HU}$ (Haugh Unit). In this project, the author discusses about how to detect the quality and freshness of the eggs using the detection of transparent objects by using GLCM (Grey Level Co-occurrence Method) and classification KNN (K-Nearest Neighbor). Therefore, this research is done with 51 images egg, with 17 images of egg $A A$ quality, 17 images of egg a quality, and 17 images of egg $B$ quality. So we get the best of $82.35 \%$ accuracy using GLCM (Grey Level Co-occurrence Matrix) with second order parameter contrast, energy, correlation, homogeneity and angle $=45$ with $d=1$ and quantization $=8$, which used classification K-NN (K-Nearest Neighbor) using distance cosine with $K=1$.

Keywords: Egg, HU (Haugh Unit), GLCM (Grey Level Co-occurrence Matrix), KNN (K-Nearest Neighbor)

1. Pendahuluan

Salah satu bahan pangan yang cepat dan praktis pengolahannya ialah telur. Selain rasa yang enak, telur pun banyak mengandung asupan yang sangat berguna untuk tubuh seperti protein, lemak, mineral, dan vitamin. Ditambah harga yang terjangkau, telur semakin dicintai oleh masyarakat Indonesia.

Namun, kandungan telur yang bermanfaat tersebut dapat rusak karena dipengaruhi oleh beberapa faktor. Kualitas telur dipengaruhi oleh kondisi lingkungan induk serta telur, pakan induk, suhu, lama penyimpanan, dan proses angkut telur. Kualitas dan kesegaran telur dapat diketahui dari ketabalan putih telur.

Tetapi, pada kenyataannya memilih telur dengan kualitas baik sulit dilakukan dengan cara manual. Cara manual yang dimaksud adalah dengan menggunakan teropong khusus (candler egg), dimana dibutuhkan mata yang jeli serta peralatan yang tidak praktis untuk menentukan kualitas telur. Selain itu, pada distributor telur seperti supermarket besar atau swalayan membutuhkan waktu yang 
lama untuk memeriksa telur satu persatu. Untuk mengurangi subjektifitas dari hal tersebut, maka dibutuhkan suatu sistem yang objektif dan mampu memangkas waktu untuk memeriksa telur. Caranya adalah dengan mengambil beberapa jumlah sampel telur dari satu tempat yang sama lalu diperiksa menggunakan sistem yang dibahas penelitian ini, karena telur dari tempat yang sama memiliki ciri relatif sama. Dari sampel tersebut, dapat diketahui kualitas dari telur dari tempat atau distributor tersebut.

Pada penelitian ini, cara meneliti kualitas telur tersebut ialah menggunakan suatu sistem yang bekerja dengan cara mendeteksi citra suatu telur siap konsumsi. Pendeteksian kualitas dan kesegaran telur dilihat dari ketebalan, kekentalan, dan ketinggian putih telurnya. Penulis menggunakan metode GLCM (Grey Level Co-occurrence Matrix) untuk ekstraksi ciri, metode KNN (K-Nearest Neighbor) untuk klasifikasi. Digunakan metode GLCM karena, metode GLCM sederhana dalam pengaplikasian namun memiliki hasil yang bagus pada percobaan telur ayam. Citra telur ayam yang akan diekstraksi berupa grayscale, agar komputasi menjadi lebih mudah. Untuk mendukung hal tersebut, maka metode GLCM dipilih untuk mengekstraksi ciri citra telur ayam.

\section{Dasar Teori}

\subsection{Telur}

Telur adalah salah satu bahan pangan yang bernilai gizi tinggi dan merupakan sumber protein hewani, khususnya asam amino esensial. Protein dalam telur memberikan pengaruh yang lebih baik daripada bahan protein lainnya karena telur memiliki zat gizi dengan daya cerna tinggi. [1,2]

Indeks albumen dapat dihubungkan dengan tinggi dan lebar albumen. Indeks albumen merupakan perbandingan antara tinggi albumen dengan diameter rata-rata albumen kental. Menurut penelitian [3], saat kondisi telur ayam segar yang baik nilai albumen berkisar antara 0.090 dan 0.120 . Namun selama penyimpanan albumen akan semakin encer akibat pemecahan protein sehingga indeks albumen akan semakin menurun. Indeks albumen dihitung menggunakan bantuan tools $\mathrm{HU}$ Micrometer (Haugh Unit Micrometer). HU merupakan satuan yang dipakai untuk mengukur kualitas telur dengan melihat kesegaran isinya. Makin tinggi $\mathrm{HU}$ makin bagus dan segar telur tersebut.

Kualitas telur berdasarkan HU menurut standar United State Department of Agriculture (USDA) adalah sebagai berikut :

1. Kualitas AA memiliki tinggi $\mathrm{HU}$ putih telur $>72$

2. Kualitas A memiliki tinggi HU putih telur 60-71

3. Kualitas B memiliki tinggi HU putih telur 31-59
4. Kualitas $\mathrm{C}$ memiliki tinggi $\mathrm{HU}$ putih telur $<31$

\subsection{Ekstraksi Ciri Grey Level Co-occurrence Matrix (GLCM)}

GLCM didefinisikan sebagai tabulasi dari data piksel citra dimana digambarkan seberapa sering kombinasi yang berbeda pada nilai keabuan yang muncul pada citra. Berikut langlah-langkah metode GLCM [4]:

\section{Quantization}

Merupakan konversi nilai grayscale (256 nilai keabuan) citra kedalam rentang (level-level) nilai tertentu. Tujuan kuantisasi ini adalah mengurangi angka perhitungan dan meringankan proses komputasi.Misalkan ditetapkan delapan rentang nilai $(0-7)$ dimana setiap rentang mewakili 32 nilai keabuan.

\section{Co-occurrence}

Kookurensi berarti kejadian bersama, yaitu jumlah kejadian satu level nilai intensitas piksel bertetangga dengan satu level intensitas piksel lain dalam jarak (distance) dan orientasi sudut $(\theta)$ tertentu $(d, \theta)$. Jarak dinyatakan dalam piksel dan orientasi dinyatakan dalam derajat. Orientasi dibentuk dalam empat arah sudut dengan interval sudut $45^{\circ}$, yaitu $0^{\circ}, 45^{\circ}, 90^{\circ}$, dan $135^{\circ}$ sedangkan jarak antar piksel ditetapkan sebesar satu piksel.

3. Symmetric

Symmetric diartikan sebagai kemunculan posisi piksel yang sama. Symmetric adalah hasil penjumlahan matrik kookurensi dengan matrik transpose nya sendiri.

$$
\text { Matriks } D=\text { Matriks } C+\text { Matriks } C^{T}
$$

\section{Normalization}

Normalization dilakukan dengan membagi setiap angka matrik pada matrik D (symmetric) dengan jumlah seluruh angka pada matrik tersebut.

\section{Feature Ecxtraction}

GLCM merupakan salah satu cara mengekstrak fitur statistik orde-kedua. Fitur yang diekstrak adalah energi, kontras, korelasi dan homogenitas[5]. Nilai energy menunjukkan ukuran sifat homogenitas citra.

Nilai energy yang tinggi muncul pada saat tekstur citra cenderung seragam.

$$
\text { Energy }=\sum_{i, j=0}^{N-1}\{p(i, j)\}^{2}
$$

Contrast merupakan perhitungan perbedaan intensitas antara piksel satu dengan piksel yang berdekatan diseluruh gambar. Kontras bernilai nol untuk gambar konstan. 


$$
\text { Contrast }=\sum_{i, j}|i-j|^{2} P(i, j)
$$

Homogenity menunjukkan kehomogenan citra yang berderajat keabuan sejenis. Citra homogen akan memiliki homogeneity yang besar.

$$
\text { Homogenity }=\sum_{i, j=0}^{N-1} \frac{p(i, j)}{1+(i-j)^{2}}
$$

Sedangkan correlation mengukur ketidakmiripan suatu gambar dimana nilainya akan besar bila acak dan bernilai kecil jika seragam.

$$
\text { Correlation }=\sum_{i, j} \frac{(i-\mu i)(j-\mu j) p(i, j)}{\sigma_{i} \sigma_{j}}
$$

Dengan nilai mean dan variansi sebagai berikut :

$$
\begin{aligned}
& \mu_{i}=\sum_{i, j} i[P(i, j)] \\
& \mu_{j}=\sum_{i, j} j[P(i, j)] \\
& \sigma_{i}=\sqrt{\sum_{i, j} P(i, j)\left(i-\mu_{i}\right)^{2}} \\
& \sigma_{j}=\sqrt{\sum_{i, j} P(i, j)\left(j-\mu_{j}\right)^{2}}
\end{aligned}
$$

\subsection{Klasifikasi KNN (K-Nearest Neighbor)}

Algoritma K-Nearest Neighbor (K-NN) merupakan sebuah metode untuk melakukan klasifikasi terhadap objek berdasarkan data uji yang jaraknya paling dekat dengan objek tersebut. Pada data latih biasanya diambil lebih dari satu tetangga terdekat dengan data uji kemudian algoritma ini digunakan menentukan kelasnya. [6]

Berikut merupakan algoritma dari klasifikasi $K$ Nearest Neighbor (K-NN):

1. Tentukan nilai $k$

2. Hitung jarak antara data baru ke setiap labeled data

3. Tentukan $k$ labeled data yang mempunyai jarak yang paling minimal

4. Klasifikasi data baru ke dalam labeled data yang mayoritas K-NN dipilih berdasarkan metric jarak

Ada berbagai cara dimana K-NN dapat digunakan untuk menentukan kelas, yaitu beberapa aturan jarak yang digunakan. Beberapa cara tersebut adalah [7]:

\section{Euclidean Distance}

Euclidean distance adalah jarak biasa antara dua titik atau koordinat yang diturunkan dari rumus phytaghoras. Euclidean distance antara titik dan adalah panjang garis yang menghubungkan keduanya ab.ab sendiri adalah sisi miring dari garis yang dibentuk pada sumbu $\mathrm{x}$ dan sumbu $\mathrm{y}$ antara koordinat a dan b. [11]:

$$
d_{s, t}=\sqrt{\sum_{j=1}^{n}\left(x_{s, j}-y_{t, j}\right)}
$$

\section{City Block Distance}

Cityblock distance adalah jarak antara dua titik atau koordinat yang mirip dengan euclidean distance. Namun sedikit berbeda dengan euclidean distance yang mengukur panjang garis yang menghubungkan kedua titik tersebut. Cityblock distance antara titik a dan $\mathrm{b}$ adalah nilai mutlak dari jarak antara a dan $b$ dari sumbu $x$ dan sumbu $y$. [8]:

$$
d_{s, t}=\sum_{i=1}^{n}\left|x_{s, j}-y_{t, j}\right|
$$

3. Cosine Similarti

Cosine similarity (cosine) adalah ukuran kesamaan diantara dua vektor dari sebuah inner product space yang mengukur kosinus dari sudut diantara dua vektor tersebut. Dalam Cosine distance, titik-titik dianggap sebagai vektor, dan dilakukan pengukuran terhadap sudut antara dua vektor tersebut.

$$
d_{s, t}=1-\cos \theta
$$

Dengan,

$$
\operatorname{Cos} \theta=\frac{x_{s} \cdot x_{t}}{\left|x_{s}\right|\left|x_{t}\right|}
$$

\section{Correlation}

Dalam Correlation distance, titik-titik dianggap sebagai barisan nilai, jarak antar nilai xs dan xt, memakai rumus sebagai berikut[9]:

$$
d_{s, t}=1-\frac{\left(\mathrm{x}_{\mathrm{s}}-\overline{\mathrm{x}_{\mathrm{s}}}\right) \cdot\left(\mathrm{x}_{\mathrm{t}}-\overline{\overline{\mathrm{t}}}\right)}{\sqrt{\left(\mathrm{x}_{\mathrm{s}}-\overline{\mathrm{x}_{\mathrm{s}}}\right) \cdot\left(\mathrm{x}_{\mathrm{s}}-\overline{\mathrm{x}_{\mathrm{s}}}\right)} \cdot \sqrt{\left(\mathrm{x}_{\mathrm{t}}-\overline{\mathrm{x}_{\mathrm{t}}}\right) \cdot\left(\mathrm{x}_{\mathrm{t}}-\overline{\mathrm{x}_{\mathrm{t}}}\right)}}
$$

Dimana,

$$
\overline{x_{s}}=\frac{1}{n}+\sum_{j} x_{s, j} \text { dan } \bar{x}_{t}=\frac{1}{n}+\sum_{j} x_{t, j}
$$

\section{Perancangan Sistem}

Pada penelitian ini, sistem perangkat lunak yang dirancang terdiri atas dua tahap, yaitu tahap pelatihan dan pengujian pada tingkat kualitas dan kesegran telur. Pada tahap latih yaitu proses pencarian nilai pixel yang menjadi acuan untuk database program, dimana nilai piksel tersebut dicocokan dengan citra uji untuk mendeteksi kelas telur ayam negeri. Dalam tahap latih digunakan citra latih sebanyak 24 citra telur dengan jumlah citra uji sebanyak 51 citra telur yang sudah dicocokkan dengan tinggi dari nilai HU dan yolk color fan. proses indentifikasi kualitas kesegaran telur dilihat dari ketinggian putih telur. 


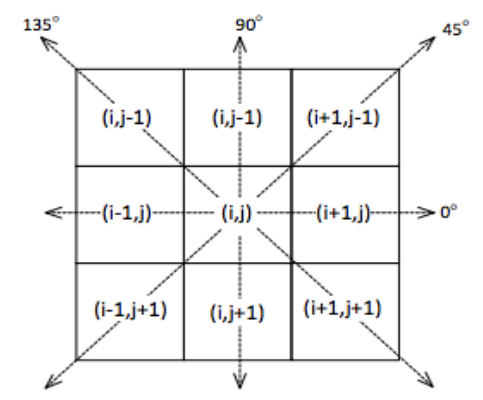

Gambar 1. Ketetanggaan Antar Piksel Sebagai Fungsi Orientasi Sudut dan Jarak

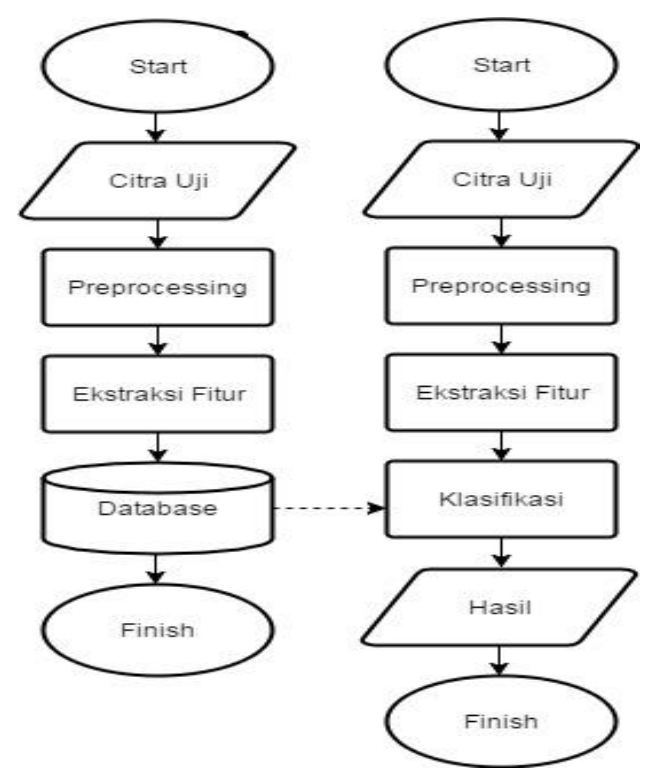

Gambar 2. Diagram Alir Sistem

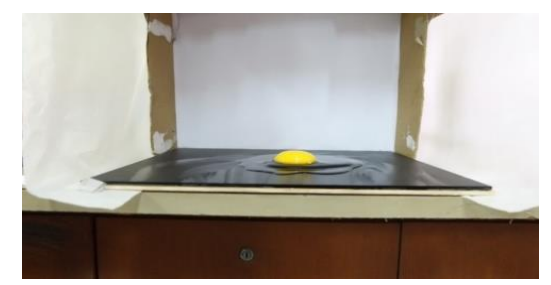

Gambar 3. Hasil akuisisi citra

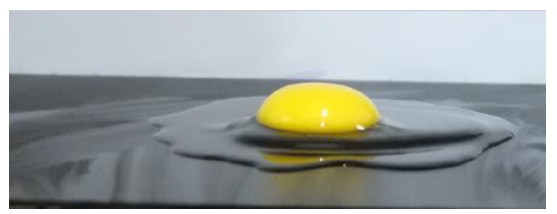

Gambar 4. Hasil cropping

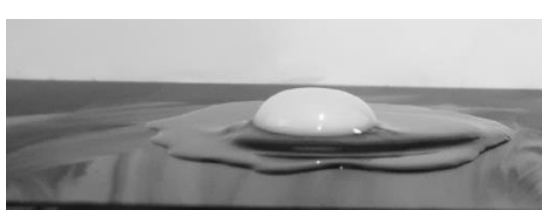

Gambar 5. Hasil Grayscale

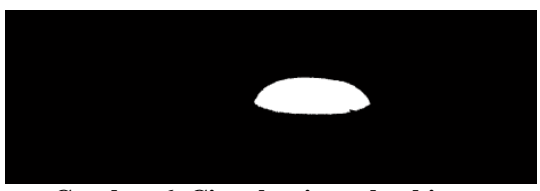

Gambar 6. Citra kuning telur biner

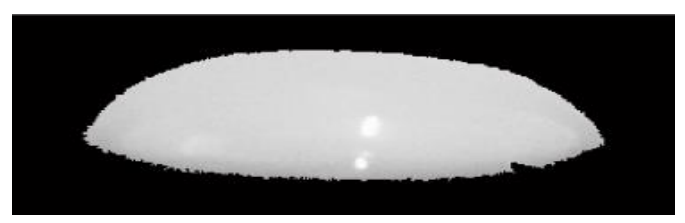

Gambar 7. Citra input ekstraksi fitur

Preprocessing yang dilakukan adalah:

1. Akuisisi Citra

Menggunakan kamera digital, pengambilan gambar dilakukan sore hari dengan alas berupa akrilik dove hitam dan latar belakang putih.

2. Cropping

Difokuskan pada citra telur saja.

3. Grayscale

Bertujuan untuk menyederhanakan citra sehingga perhitungan yang dilakukan tidak terlalu kompleks.

4. Thresholding, BWareaopen, Filling

Dilakukan untuk menyempurnakan citra kuning telur yang akan diproses. Thresholding menghitamkan area diluar cakupan thresholding dan member warna putih pada bentuk kuning telur. BWareaopen menghilangkan area kecil yang tidak digunakan. Filling mengisi lubang yang terbentuk pada citra kuning telur hitam-putih.

5. Pengukuran dimensi kuning telur

Pada tahap ini, tinggi putih telur diukur berdasarkan bentuk kuning telur. Tinggi diukur dari batas atas dan batas bawah citra. Acuannya adalah, citra kuning telur yang mencuat disisisisi karena bayangan yang timbul akibat putih telur.

6. Cropping dan citra grayscale

Citra kuning telur biner yang sudah diukur tingginya kemudian di fokuskan lagi sehingga yang tampak tanpa latar belakang. Kuning telur yang masih berwarna putih, dikembalikan ke warna asal (grayscale) untuk menjadi input ekstraksi fitur.

Pada sistem ini, data dibagi menjadi 3 kualitas kesegaran telur ayam menurut Haugh Unit (HU), yaitu:

1. Kualitas AA memiliki tinggi (HU USDA) putih telur $>72$.

2. Kualitas A memiliki tinggi (HU USDA) putih telur 60-71.

3. Kualitas B memiliki tinggi (HU USDA) putih telur 31-59. 
Tabel 1. Hasil pengujian parameter orde dua GLCM

\begin{tabular}{|c|c|c|c|}
\hline Arah & Akurasi & $\begin{array}{c}\text { Waktu } \\
\text { Komputas } \\
\text { i }\end{array}$ & $\begin{array}{c}\text { Jumlah Data } \\
\text { Benar }\end{array}$ \\
\hline $0^{\circ}$ & $64.71 \%$ & 0.4041 & 33 \\
\hline $45^{\circ}$ & $80.39 \%$ & 0.4051 & 42 \\
\hline $90^{\circ}$ & $70.59 \%$ & 0.4035 & 36 \\
\hline $135^{\circ}$ & $66.67 \%$ & 0.4330 & 34 \\
\hline
\end{tabular}

Tabel 2. Hasil pengujian arah dan jarak GLCM

\begin{tabular}{|c|c|c|c|c|}
\hline \multirow{2}{*}{ Arah } & jarak & akurasi & $\begin{array}{c}\text { waktu } \\
\text { komputasi }\end{array}$ & $\begin{array}{c}\text { Jumlah } \\
\text { Data } \\
\text { Benar }\end{array}$ \\
\hline \multirow{3}{*}{0} & 1 & $64.71 \%$ & 0.4041 & 33 \\
\cline { 2 - 5 } & 2 & $68.63 \%$ & 0.4104 & 35 \\
\cline { 2 - 5 } & 3 & $74.51 \%$ & 0.4196 & 38 \\
\hline \multirow{4}{*}{45} & 1 & $80.39 \%$ & 0.4051 & 41 \\
\cline { 2 - 5 } & 2 & $56.86 \%$ & 0.4064 & 29 \\
\cline { 2 - 5 } & 3 & $58.82 \%$ & 0.4070 & 30 \\
\hline \multirow{3}{*}{90} & 1 & $70.59 \%$ & 0.4035 & 36 \\
\cline { 2 - 5 } & 2 & $56.86 \%$ & 0.4063 & 29 \\
\cline { 2 - 5 } & 3 & $54.90 \%$ & 0.4079 & 28 \\
\hline \multirow{3}{*}{135} & 1 & $66.67 \%$ & 0.4430 & 34 \\
\cline { 2 - 5 } & 2 & $50.98 \%$ & 0.4090 & 26 \\
\cline { 2 - 5 } & 3 & $49.02 \%$ & 0.4061 & 25 \\
\hline
\end{tabular}

Tabel 3. Hasil pengujian level kuantisasi GLCM

\begin{tabular}{|c|c|c|c|c|}
\hline $\begin{array}{c}\text { kuant } \\
\text { isasi }\end{array}$ & jarak & akurasi & $\begin{array}{c}\text { waktu } \\
\text { komputasi }\end{array}$ & $\begin{array}{c}\text { Jumlah } \\
\text { Data } \\
\text { Benar }\end{array}$ \\
\hline \multirow{3}{*}{8} & 1 & $\begin{array}{c}80.39 \\
\%\end{array}$ & 0.4051 & 41 \\
\cline { 2 - 5 } & 2 & $\begin{array}{c}56.86 \\
\%\end{array}$ & 0.4064 & 29 \\
\cline { 2 - 5 } & 3 & $\begin{array}{c}58.82 \\
\%\end{array}$ & 0.4070 & 30 \\
\hline \multirow{3}{*}{16} & 1 & $\begin{array}{c}47.06 \\
\%\end{array}$ & 0.4096 & 24 \\
\cline { 2 - 5 } & 2 & $\begin{array}{c}45.10 \\
\%\end{array}$ & 0.4063 & 23 \\
\cline { 2 - 5 } 32 & 3 & $\begin{array}{c}45.10 \\
\%\end{array}$ & 0.4056 & 23 \\
\hline \multirow{3}{*}{3} & 1 & $\begin{array}{c}41.18 \\
\%\end{array}$ & 0.4069 & 21 \\
\cline { 2 - 5 } & 2 & $\begin{array}{c}37.25 \\
\%\end{array}$ & 0.4057 & 19 \\
\hline
\end{tabular}

\section{Analisis}

\subsection{Pengujian Menggunakan Parameter Orde Dua GLCM}

Pengujian pada tahap ini menggunakan parameter orde dua GLCM (kontras, energy, korelitas, homogenitas) dengan $\mathrm{d}=1$, level kuantisasi 8 dan parameter $\mathrm{KNN} \mathrm{k=1}$ distance Euclidean.

Digunakan parameter orde dua tersebut karena ketika diujikan dengan parameter orde dua kontrasenergi dan korelitas-homogenitas hasil akurasi yang didapatkan lebih kecil. Hal tersebut disebabkan karena semakin beragam parameter orde dua yang digunakan, semakin banyak cirri yang didapat, maka semakin bagus pula akurasi yang didapatkan.

\subsection{Pengujian Pengaruh Arah dan Jarak pada GLCM}

Pada tahap ini akan diuji pengaruh jarak dan arah pada GLCM. Parameter jarak yang digunakan adalah $\mathrm{d}=1,2,3$ arah $0^{\circ}, 45^{\circ}, 90^{\circ}, 135^{\circ}$ level kuantisasi 8 parameter orde dua kontras, energy, korelasi, homogenitas dan parameter $\mathrm{KNN} \mathrm{k}=1$ distance Euclidean.

Berdasarkan Tabel 2 akurasi terbesar didapatkan pada saat parameter arah $45^{\circ}$ dengan jarak sebesar 1 pixel, yaitu $80.39 \%$. Sedangkan akurasi terkecil pada parameter arah $135^{\circ}$ dengan jarak sebesar 3 piksel, yaitu $49.02 \%$. Hal ini karena ketetanggaan GLCM banyak terdapat pada arah $45^{\circ}$ dengan jarak sebesar 1 piksel.

\subsection{Pengujian Pengaruh Parameter Kuantisasi pada GLCM}

Pada pengujian ini menggunakan parameter jarak yang $\mathrm{d}=1,2,3$, arah $45^{\circ}$, level kuantisasi $8,16,32$ parameter orde dua yang digunakan kontras, korelasi, energy, dan homogenitas, dimana parameter $\mathrm{KNN} \mathrm{k}=1$ distance Euclidean.

Berdasarkan tabe 13 akurasi terbesar didapatkan pada saat level kuantisasi 8 dan jarak $\mathrm{d}=1$ yaitu sebesar $80.39 \%$ dan akurasi terkecil pada saat level kuantisasi 32 pada jarak $\mathrm{d}=2$ dan $\mathrm{d}=3$ yaitu sebesar $37.25 \%$. Hal ini terjadi karena pada kuantisasi 8 lebih banyak ciri yang termasuk dalam kelas yang benar. Semakin besar kuantisasi, semakin kecil range nilainya, maka semakin besar pula peluang kesalahan.

\subsection{Pengujian Menggunakan Parameter Nilai $\mathrm{K}$ pada KNN}

Pada tahap ini akan diuji pengaruh Nilai K pada KNN. Parameter jarak yang digunakan adalah 
Tabel 4. Hasil pengujian nilai K pada KNN

\begin{tabular}{|c|c|c|c|c|}
\hline $\begin{array}{c}\text { Nilai } \\
\mathrm{k}\end{array}$ & Jarak & $\begin{array}{c}\text { Akuras } \\
\mathrm{i}\end{array}$ & $\begin{array}{c}\text { waktu } \\
\text { komputasi }\end{array}$ & $\begin{array}{c}\text { jumlah } \\
\text { data } \\
\text { benar }\end{array}$ \\
\hline \multirow{3}{*}{1} & 1 & $80.39 \%$ & 0.4051 & 41 \\
\cline { 2 - 5 } & 2 & $56.86 \%$ & 0.4064 & 29 \\
\cline { 2 - 5 } & 3 & $58.82 \%$ & 0.4070 & 30 \\
\hline \multirow{3}{*}{3} & 1 & $74.51 \%$ & 0.5047 & 38 \\
\cline { 2 - 5 } & 2 & $52.94 \%$ & 0.4075 & 27 \\
\cline { 2 - 5 } & 3 & $52.94 \%$ & 0.4070 & 27 \\
\hline \multirow{3}{*}{5} & 1 & $62.75 \%$ & 0.4064 & 32 \\
\cline { 2 - 5 } & 2 & $54.90 \%$ & 0.4049 & 28 \\
\cline { 2 - 5 } & 3 & $39.22 \%$ & 0.4062 & 20 \\
\hline \multirow{3}{*}{7} & 1 & $70.59 \%$ & 0.4073 & 36 \\
\cline { 2 - 5 } & 2 & $45.10 \%$ & 0.4075 & 23 \\
\hline & 3 & $43.14 \%$ & 0.4072 & 22 \\
\hline
\end{tabular}

Tabel 5. Hasi pengujian distance pada KNN

\begin{tabular}{|c|c|c|c|c|}
\hline distance & $\begin{array}{c}\text { Nilai } \\
\mathrm{k}\end{array}$ & akurasi & $\begin{array}{c}\text { waktu } \\
\text { komputasi }\end{array}$ & $\begin{array}{c}\text { jumlah } \\
\text { data } \\
\text { benar }\end{array}$ \\
\hline \multirow{5}{*}{ euclidean } & 1 & $80.39 \%$ & 0.4051 & 41 \\
\cline { 2 - 5 } & 3 & $74.51 \%$ & 0.5047 & 38 \\
\cline { 2 - 5 } & 5 & $62.75 \%$ & 0.4064 & 32 \\
\cline { 2 - 5 } city block & 7 & $70.59 \%$ & 0.4075 & 36 \\
\hline & 1 & $76.47 \%$ & 0.4079 & 39 \\
\cline { 2 - 5 } & 3 & $68.63 \%$ & 0.4074 & 35 \\
\hline & 5 & $72.55 \%$ & 0.4087 & 37 \\
\hline \multirow{5}{*}{ Cosine } & 7 & $70.59 \%$ & 0.4096 & 36 \\
\cline { 2 - 5 } & 1 & $82.35 \%$ & 0.4125 & 42 \\
\cline { 2 - 5 } & 3 & $74.51 \%$ & 0.4081 & 38 \\
\cline { 2 - 5 } & 5 & $68.63 \%$ & 0.4065 & 35 \\
\hline & 7 & $72.55 \%$ & 0.4138 & 37 \\
\hline \multirow{5}{*}{ Correlation } & 1 & $58.82 \%$ & 0.4084 & 30 \\
\cline { 2 - 5 } & 3 & $60.78 \%$ & 0.4059 & 31 \\
\cline { 2 - 5 } & 5 & $66.67 \%$ & 0.4066 & 34 \\
\hline & 7 & $64.71 \%$ & 0.4064 & 33 \\
\hline
\end{tabular}

$\mathrm{d}=1,2,3$ arah $45^{\circ}$ level kuantisasi 8 parameter orde dua kontras, energi, korelasi, homogenitas dan parameter $\mathrm{KNN} \mathrm{k}=1,3,5,7$ distance Euclidean. Berdasarkan Tabel 4 akurasi terbesar didapatkan pada saat parameter $\mathrm{k}=1$ dan jarak $\mathrm{d}=1$ yaitu sebesar $80.39 \%$ dan akurasi terkecil pada saat parameter $\mathrm{k}=5$ dan jarak $\mathrm{d}=3$ yaitu sebesar $39.22 \%$. Hal ini disebabkan karena ketika $\mathrm{k}=1$, banyak terdapat ketetanggaan pada data uji dan data latih, sehingga data tersebut mampu diklasifikasikan secara tepat

\subsection{Pengujian Parameter Distance pada KNN}

Pada pengujian tahap ini, parameter yang digunakan adalah $\mathrm{k}=1$ distance Euclidean, city block, cosine, correlation sedangkan parameter GLCM orde dua kontras, energy, korelasi, homogenitas dengan $\mathrm{d}=1$ kuantisasi 8 arah $45^{\circ}$. Berdasarkan tabel 5 akurasi terbesar didapatkan pada saat $\mathrm{k}=1$ dan distance euclidean yaitu sebesar 82.35 $\%$ dan akurasi terkecil pada saat $\mathrm{k}=1$ distance correlation sebesar $58.82 \%$. Hal ini disebabkan karena ketika menggunakan perhitungan vektor, lebih banyak kesamaan yang didapat oleh data uji ketika dibandingkan dengan data latih, sehingga bisa diklasifikasikan kedalam kelasnya secara lebih akurat.

\section{Kesimpulan}

Berdasarkan hasil pengujian yang dilakukan pada sistem pengklasifikasian citra telur pada penelitian ini, didapatkan kesimpulan sebagai berikut:

1. Sistem ini sudah mampu mengklasifikasikan jenis kualitas telur menggunakan metode GLCM dengan klasifikasi K-NN

2. Sistem klasifikasi jenis kualitas telur dilakukan dengan tahapan akuisisi citra berupa pengambilan citra menggunakan kamera digital. Kemudian dilanjutkan dengan preprocessing. Lalu ekstraksi ciri pada GLCM. Terakhir klasifikasi jenis kualitas telur dengan K- NN.

3. Parameter arah terbaik adalah sebesar $45^{\circ}$, jarak sebesar 1 pixel dan parameter orde dua menggunakan kontras, korelasi, energy dan homogenitas.

4. Jenis jarak paling baik pada K-NN adalah Euclidean dan nilai $\mathrm{k}$ yang paling baik adalah $\mathrm{k}=1$ sehingga didapat hasil klasifikasi yang paling optimal.

5. Akurasi terbesar adalah $76.4 \%$ dengan parameter $\mathrm{d}=1$ kuantisasi 8 arah $45^{\circ} \mathrm{GLCM}$ dan $\mathrm{k}=1$ distance Euclidean pada K-NN dan waktu komputasi sebesar 0.4094s.

\section{Saran}

Sistem deteksi kesegaran dan kualitas telur ini masih dapat dikembangkan, sehingga tingkat akurasi yang diperoleh lebih besar dan akurat tanpa 
membutuhkan waktu komputasi yang lama. Oleh karena itu, adapun saran untuk pengembangan penelitian ini selanjutnya yaitu perlu:

1. Menggunakan tahap preprocessing lain yang lebih baik agar menghasilkan ciri yang lebih baik juga pada tahap ekstraksi cirinya.

2. Menggunakan metode yang berbeda untuk mendeteksi jenis kualitas telur, agar dapat dibandingkan metode mana yang lebih baik. GLCM merupakan ekstraksi fitur untuk struktur, ada baiknya jika menggunakan metode untuk ekstraksi cirri bentuk agar akurasi yang didapat semakin bagus.

3. Mengambil sempel lebih dari 1 tempat peternak telur ayam untuk perbandingan.

4. Mengambil sampel dari berbagai macam distributor.

\section{Daftar Pustaka}

[1] Tim Praktikum Produksi Ternak Unggas, "Penuntun Praktikum Produksi Ternak Unggas”, Bandung: Universitas Padjadjaran, 2013.

[2] Sudaryani, T., “Kualitas Telur”, Jakarta: Penebar Swadaya, 2003.

[3] Suardana, I.W. dan I.B.N Swacita., "Higiene Makanan", Denpasar: Udayana University Press, 2009.

[4] Hall-Beyer, Mryka., (2017, Maret), "Gray Level Co-occurrence Matrix",. [online]. Tersedia di: http://www.fp.ucalgary.ca/mhallbey/the_glcm.h tml.

[5] Putra, Darma, "Pengolahan Citra Digital", Yogyakarta: ANDI, 2010.

[6] Nobertus, K dkk, "Algoritma K-Nearest Neighbor Dalam Klasifikasi Data Hasil Produksi Kelapa Sawit pada PT. Minamas Kecamatan Parindu”, 2013.

[7] Rohmatullah, M., "Identifikasi Citra Pada Plat Nomor Kendaraan Mobil Pribadi Menggunakan Metode K-Nearest Neighbor”, Bandung: Telkom University, 2015.

[8] A.F, Basuki., "Deteksi Kualitas dan Kesegaran Telur Berdasarkan Segmentasi Warna dengan Metode Fuzzy Color Histogram dan Wavelet dengan Klasifikasi K-NN”, Bandung : Telkom University, 2014.

[9] V, Apryaleva, "Simulasi dan Analisis Sistem Klasifikasi Batubara Menggunakan Discrete Wavelet TRansform(DWT), Fuzzy Color Histogram (FCH) DAN K-Neares Neighbor $(K$ NN) Pada Citra Digital” pp. 1-8, 2015. 